\title{
THE OMNIPRESENT EVIL IN HARDY'S THE MAYOR OF CASTERBRIDGE
}

\section{Dr. MOUMITA DEY}

HoD \& Assistant Professor, Department. of English, Holy Cross College, Agartala, Tripura, India

Received: Apr 25, 2020; Accepted: May 16, 2020; Published: Jun 01, 2020; Paper Id.: IJELJUN20203

\section{INTRODUCTION}

Hardy's WESSEX can be said to be a 'land of evils' which heightens the gloomy atmosphere in his pessimistic world. 'Fate', 'Chance' and 'Co-incidences', no doubt play fair roles to contribute to his dark plots, but there happens to be an internal element in each of these three important instruments that Hardy employs. The internal element seems to be an inherent attribute of all these three instruments of Hardy. This element can be referred to as the 'inherent evil', which compels 'Fate', 'Chance' and 'Co-incidences' to interact with one another, associate themselves with the other and forces and directs men into wrong deeds and actions. This 'inherent evil', is in fact, an innate phenomenon that is ever-present and has several forms in which it can be seen operating in his world, from behind the scene. 'The Mayor of Casterbridge', similar to other novels of Hardy is possessed with this innate omnipresent 'inherent evil' throughout.

\section{LITERATURE REVIEW}

Scholars have discussed that Fate, Chance and Co-incidence are the essential elements in Hardy's novels that bring about the sufferings of his protagonists. As Venkatasamy (2016) points out that as in other novels of Hardy, even in The Mayor of Casterbridge, Hardy uses coincidences to keep the interest of his audience bound to otherwise not so real life circumstances. He highlighted that Hardy uses the technique of coincidences primarily to show the story of a man's struggle against his own Fate. However, apart from the combined effect of these elements, there lies the presence of a fourth element, which I refer to as the 'inherent evil', which equally plays a dominant role in causing the downfall of the protagonists in Hardy's pessimistic world. This can also be inferred from the view that apart from circumstances, Hardy's characters, and so for that matter Henchard, in the present novel, suffers not just 
owing to his circumstances but also because of his passions, as has also been stated by Naji (2012).

Further, the character of Henchard is said to have undergone the tragic end owing to his Fate. There are also instances where scholars have reflected upon this downfall of the main character of Henchard and have seen his downfall to be related with the life and activities of other characters that surround him (Hussain, 2015). However, my argument in this context is that unless a person has, within himself, evil traits and evil attitudes, neither Fate nor others related to him, can bring about such a massive downfall like that of Henchard's, from whom is cut off every thread of hope and love when he stands at the edge of his life.

Therefore, Henchard is believed to be that central character of Hardy who is presented more as an antagonist rather than a protagonist (Caroll, et.all., 2010). He is presented as a man by Hardy, whose disposition, arrogant attitude and despotism are owing to the sprite within him. Thus, he is a man, with fiend within him since the beginning of the story. So when Hardy states that the novel is about the story of a man of character he is, in reality, presenting a demon, under the mask of a man.

From the social domain too, incidences such as the organization of the skimmity ride, by Jopp and his friends, which Carpenter (1976) terms as unreal, hallucination or the reflections of the agitated inner states of the characters, is in itself highly disgraceful. It stands out as the most insane act of disrespect on part of Jopp towards his ex-employer, Michael Henchard and an act of social humiliation on part of Lucetta, the wife of the present Mayor of the city of Casterbridge and is above all, the mortification of the honour of woman in general. Beside this, there are several other instances in the novel that marks, following Hussain (2015) that the plight of women in the $19^{\text {th }}$ century England was rather critical. These actions of the men of the Victorian society are rather the evidences of the presence of the inherent evil even at the societal level.

\section{ANALYSIS}

The tragic hero - Michael Henchard - sells his wife under the effects of intoxication, but regrets about it the next day in his consciousness. This action of his at the onset of the plot rightly hints at his evil nature. It can be said that the evil trait, hidden within, gets an upper hand under the effect of intoxication and made him speak out the real truth, which he otherwise could not have uttered in conscious self. We can say that there must have been the evil thought of getting rid off of his wife and daughter, working under the conscious level of his thoughts, which lay hidden, and have been struggling deeper within his self to emerge out. When he gets intoxicated, as is the case with many others, Henchard lost the control over his conscious mind and it was then when the evil inherent within him, exercised its superiority, making Henchard commit the most devilish sin of the cosmos that of biding his own legal wife and daughter off to the stranger, Newson.

The 'inherent evil' that we aim to examine in the novel could be categorized into different types, based on how they get surfaced in different but individual characters, in a given situation, at a particular moment in the novel. As every situation is different, so the evil comes to focus in different forms in different situations in different individuals. It depends on a particular individual as to how far one can handle the pressure of the situation he is exposed to and only when one finds it utterly difficult, or beyond one's capability to handle the pressure, then one is forced to react to that external pressure and the inherent evil, then, finds a form of expression in that individual readily with ease.

One such instance is seen when the social evil of marrying a lady, under pressure - from family and from society - against his wish might have given birth to the personal evil that we see in the character of Michael Henchard right in the opening 
scenes of the plot.

\section{The Communal Evil}

The presence of social evil is evident in the very beginning because marriage is a union that needs the consent of the two individuals, steeping into the bond of a relationship. However, the Victorian society must have not given the due respect to the individual consents and owing to which Henchard and Susan must have had to marry, under pressure, against their wishes to do so. Thus, Henchard was never mentally set to take upon the responsibilities of a family at an early age. He must have been a person of dreams which got curbed down owing to the family responsibilities. His ambitions, as a youth, suffered under the pressure of meeting his family's requirements of food and shelter, which had not given him enough freedom to think about his career. Thus, he felt that the responsibilities of his wife and daughter were thrust upon him and it was therefore a burden on his shoulders, which he subconsciously wanted to overcome.

This act of selling his wife and daughter is also symbolic of the patriarchal dominance of the $19^{\text {th }}$ century WESSEX. This patriarchal dominance is also prominently found in Henchard's responses to Lucetta. At his own ease, we find Henchard, the man, accepting Lucetta; then rejecting her with a monetary compensation; and then wish her back in his life again. The materialistic compensation that he pays to Lucetta is also an attestation enough to prove the patriarchal dominance in the Victorian society.

This dominance is also highly visible when Henchard, post his remarriage with Susan, expects Elizabeth Jane to adopt the ways and attributes of the rich bureaucratic society of the town and change herself. This includes the change in her surname from Newson to Henchard, along with the adaptaion of the manners and preferences of the upper class society of the town. This was to assure that she was under Henchard's security now that she was formally adopted by him. As such he wanted to exercise complete authority not only over his wife Susan, but also over his adopted daughter, Elizabeth. Thus, it is evident that the condition of women in the southern England of the era was highly grave.

We can see it in the light of the fact that a man, whether rich or poor, young or old, seeks the emotional support of a woman always, probably because the absence of a lady in his life makes the man's life null and void. However, the man has always failed to realize the importance of the lady in his life and value her, which makes him neglect her presence in his life. This is when the man thinks he is superior over the lady and therefore has the authority to take decisions for her, even if his actions fetched disrespect to the lady. This is exactly why Henchard could so easily sell off Susan and later betrays Lucetta to remarry Susan and why Farfarae could betray Elizabeth to marry Lucetta.

Another social evil - probably the greatest in the humanity - is the bidding and sale of one's own wife. Though Hardy makes Henchard do so under the effects of intoxication, and not in his conscious self, such an act, anyway is a sin. Hardy must have been moral man, that is why he made the tragic hero - Michael Henchard - undergo the sin not consciously but sub-consciously. What-so-ever might be the case, the 'thought' of selling off one's own wife is taken to be the most sinful act that a man can indulge in on this earth.

Secondly, Hardy includes such an action in his plot to tell about the social sins in which men of the Victorian society were engaged and as a reformer, he took upon himself the task of eradicating these evils from the society, by creating general awareness. It can be inferred that such activities of selling one's wife had been common in the rural sectors. What results from this were the social vices, owing to which the innocent women folk of the era suffered and children lost their lives. 
Besides, Hardy also touches upon the issue of female nuisance - another critical communal evil of the Victorian society - in which the furmity woman was engaged in. Though he does not explicitly tell us about the type and kind of female nuisance, yet he includes it in his plot, to make his readers realize its unlawful significance and the fact that such evil practices in the society need be strictly prohibited by law. It can also be viewed as an urge by the novelist to take strict actions against such prevailing crimes in the society.

Another glimpse that shows the evil-mindedness of the Victorian society was that people like Jopp and his friends enjoyed the very personal letters of Lucetta and Henchard in public. As it reflects, the society was filled with insane and cynical people, for they fetched happiness in others' pains and sufferings.

\section{The Evil of Supremacy}

Another very crucial established evil of the Victorian men was their treatment of women as playful objects - one could play with them and their emotions. The men could reject a woman, when a better option was available and could go back to the earlier woman, when the latter was unavailable or if one desired to. The question that can be raised is why only men and not women did exercise the right to either select or reject their partners. Both Susan and Elizabeth were the real victims of this emotional evil of superiority of the Victorian men - Henchard and Farfare, respectively, for it were the men who emotionally attracted the women and then subsequently detached them from their emotions, only to re-build their emotional associations with them laters.

Lucetta, was also a victim of this emotional game of exercising one's authority, and only because she was herself possessed with a sense of passionate intentions of winning over men of her choice, she is the only woman, who could escape the clutches of these evil, playful intentions of supremacy of the Victorian men in her vicinity.

The death of Henchard's daughter, the baby Elizabeth Jane, who was also sold off along with Susan, can also be viewed in this light. It could be that the change of place from Casterbridge to Canada, led to the deteoriation in her health, as she was hardly some months old then. However it could also be that the sailor Newson must have failed to take adequate care of the little one as a father should have, as he probably did not feel emotionally attached with her, who wasn't his own blood. It could well be that Newson did not want to take the responsibilities of Henchard's daughter, nor did he want to nurture her. Susan, being feeble as always and a typical Victorian woman, always dependent on men, who hardly had a say of their own, could not protect the little Elizabeth. Thus, the death of Elizabeth Jane Henchard, within three months after they left Casterbridge, infact, questions the reasons of her death within so short a time.

The question of the ill-treatment of the baby Elizabeth at the hands of Newson, can be related to the harsh attitude that Henchard shows towards Elizabeth Jane Newson, later, in the story, after Susan's death, when Henchard learns from Susan's letter to him, that his adopted daughter, Elizabeth, is not his own blood, but Newson's. Henchard's changed, offputting behavior towards Elizabeth and his subsequent ill-treatment of her shows that Victorian men did not like to nurture the offsprings that their wives gave birth to from earlier relationships. In fact, these men could not accept other men's blood as their own wards and therefore, could not be affectionate towards them.

This is another instance of the 'innate evil' which makes a man ill-treat others and mentally pressurize their adopted children, to the level of torturing them, which compelled these children to take harder decisions for themselves. In this novel, we see that owing to the immense mental demands that Henchard exercised on young Elizabeth, forcing her undergo a change in her overall personality, Elizabeth was bound to leave Henchard's mansion. Had Henchard not been 
possessed with this innate evil of exerting his superior authority over her, he would have not forced Elizabeth to change even her surname from Newson to Henchard, or of impending upon Elizabeth to alter accent, her handwriting or her manners.

This 'inherent evil' in men shows itself and makes the men reject, insult and betray the lady when he feels he can survive without her presence in his life. Thus, the evil of superiority in these Victorian men forces them into such actions, for which though the men suffers for their mistakes and wrong decisions, it is the women who falls prey to the evil of men's superiority and undergoes the sufferings heavily. The women lot seems to have absolutely no control over their treatment and sufferings at the hands of these psychologically disturbed Victorian men.

Interestingly, though these men reject and cheat the women in their lives, they are brought back to them later by the rule of Destiny, which is even more superior to the inherent evil of superiority in these men. These men pay for their betrayal and insults and finally are brought back to these women, whom they had once rejected, and are not united to other women, who they aspired for. Henchard rejected Susan but was destined to re-marry Susan later and not Lucetta. He cheats Lucetta and pays her compensation for not keeping the promise of marriage with her. However, having no one to depend upon after Susan's death, he once again fetches for Lucetta and wants her as his wife at every price. It is also the character of Farfare who deceives Elizabeth for Lucetta but after the latter's unpredicted death, realizes his mistakes and consolidates with the former. These men are thus, made to pay heavily, for the evil intentions they possess, in the form of deaths of their loved ones and physical separations, leading to emotional vainness.

\section{The Evil of Persona}

As an individual, Henchard, never loved his wife, Susan, and this dislike got vent under the effects of drink in the opening scenes. Had he had an option to discard his wife, consciously, in his society, he would have done so but we find him morally bound to the norms of the society. But the inherent personal evil, within him, surfaces again and again, with the slightest provocation.

He becomes the Mayor and gets into an illegal relationship with a lady who is pretty but closer to the age of his daughter. He seems to be so highly impressed with this girl that he even promises to marry her. Had he been morally bound to his sold wife, Susan, he would have never been attracted to even the most beautiful women around him. But 'the evil greed', within him, inclined him into an immoral relationship with Lucetta. Even later, after Susan's death, it was actually quite easy for Henchard to approach Lucetta for marriage, which proves that he had never been loyal to Susan, even after her death. Henchard, is thus, possessed by the inherent evil, which makes him get involved with Lucetta whenever he gets a chance to do so. This is very much present in the character of Henchard and emerges out when he fails to curb it down inwardly, under stronger situational stimulus.

Beside Henchard, even Farfarae, is possessed with the same 'inherent evil', for after Lucetta's death, he expects to marry Elizabeth Jane, though he deceives Elizabeth for Lucetta earlier.

Elizabeth Jane Newson, on her part, is also not without the inherent evil. When Henchard, realizing Newson's presence in Casterbridge, two years later after Lucetta's death, left Casterbridge for Weydon-Priors, Elizabeth was indeed sad about it and even wept owing to the physical separation from Henchard, considering Henchard to be her own father, with whom she had got attached to emotionally. She took care of Henchard for over the last two years as a true daughter and also loved him with an affectionate heart. She wanted Henchard to stay with her and be a support to her. 
However, when Newson later, informed Elizabeth about Henchard's lie to him about Elizabeth's survival, she was extremely upset and horrified at the thoughts of Henchard. It was owing to this that when Henchard had come to wish her for their new married life, she could not withstand Henchard's sight and happened to abuse him, forgetting her past attachments with him. All her past affections and love wash away with her rebukes and harsh words for Henchard, whom she considered to be the ultimate cause of all her sufferings and pains, by keeping her away from Newson for these many years.

However, she fails to realize Henchard's emotions behind this. Had Elizabeth been thoughtful enough, she would have realized Henchard's fear of losing his only relation, his only daughter, his only hope, his only support and his only love in his life - the reasons behind Henchard's lie to Newson. Had she been able to tame down the 'inward evil' spirit within herself, she could have had a deeper insight into Henchard's feelings, which she did at length, but co-incidentally, only after the death of Henchard. As such her realizations about Henchard's emotions, were not fruitful.

In addition to this, Elizabeth's marriage with Farfare, following her later courtship with him, raises questions in the reader's mind about her evil greed, which is strong enough to curb down her self-respect, for she had been rejected by the same Farfare earlier, for Lucetta. Had Elizabeth the self-pride, she would have had a deeper thought about her reestablished relationship with Farfare. She could have shown the womanly respect by not accepting Farfare after Lucetta's death. It is quite expected from Farfare to once again reject her, had Farfare found another woman similar to Lucetta. Believing Farfare, in this regard, was more of a foolish behavior on part of Elizabeth. She should not have trusted him that blindly, but must have questioned him. Thus, she is not devoid of the Victorian 'greed' which marks the age. Her greed for Farfare's love had forced her to sacrifice her self-esteem.

Lucetta, being filled with the evil greed, to live a luxurious life, was fascinated towards the prospering Farfare, abandoning Henchard. Though, after Susan's death, she wisely crafted a plan to win over Henchard again, but she gripped the better man, comparing the two. Her

sudden collapse, witnessing the skimmity ride, showed the lack of trust that forms the base of every true relationship. However, this marriage with Farfare in reality enabled her achieve the bigger dream of becoming the Mayor's wife, ultimately, as Farfare within a short span of time after his marriage became the next Mayor of the city of Casterbridge. Therefore, she is found guilty of two things - her illegal affair with the ex-Mayor and that she hid the truth of her past relation from her husband, Donald Farfare. Thus, her evil-natured passions are explicitly presented by Hardy.

\section{CONCLUSIONS}

As such being evil was deeply rooted and hard-ingrained in the hearts of most men and women of Hardy's WESSEX in the Victorian Age, which was the ultimate cause of their miseries, sorrows and psychological strains in their lives. 'Chance', 'co-incidences' did play to bring about the resultant events but without the evil spirits acting in people's personal, social life, the factors of 'chance' and 'co-incidences' would not have seek an opportunity to play its role.

Also it is certain that there were loopholes in every sphere of life, owing to the prevailing 'evils' in and around every individual, which paved an easy access to the external factors of 'chances' and 'co-incidences' to act. The inherent evils and ills were the internal factors, which needed to be cured and healed, to relief the Victorian society of its hardships. 


\section{REFERENCES}

1. Hardy, Thomas. The Mayor of Casterbridge. Feedbooks. Gutenberg. 1886

2. Narayan, R. K. The Guide. Indian Thought Publications. 2007

3. Asha, M. "Forgiveable and Formidable Female: A Thematic Analysis in Thomas Hardy's The Trumpet Major and the Mayor of Casterbridge." Impact: International Journal of Research in Humanities, Arts and Literature (Impact: Ijrhal)3. 1, Jan 2015, $1-6$

4. Caroll, Joseph, et all. Quantifying Tonal Analysis in The Mayor of Casterbridge. Style: Vol 44, No. 1\& 2, pg. $164-189$. Spring / Summer. 2010

5. Hussain, Tazir. The Mayor of Casterbridge: Attitude Towards Changes and Challenges of Social Conventions. International Journal of Scientific and Research Publications, Vol 5, pg 1-3. 2015

6. Ikeokwu, Enyinnaya Samuel. "Marking Gender Differences in Literary Dialogue: A Linguistic Study of Two Contemporary Igbo Plays." International Journal of English and Literature (Ijel) 3.4, Oct 2013, 23-36

7. Carpenter, Richard. Thomas Hardy. The Macmillan Press Limited. London and Basingstoke. 1976

8. Venkatasami, V. E. Coincidences in Hardy's 'The Mayor of Casterbridge'. LangLit, Vol 2, issue 4, pg 816 - 819. 2016

9. Handour, Mohamed. "The Image of Women in Late Victorian Times: The Case of "The Mandrake Venus", "A White Night", and "The City Of Blood"." International Journal of English and Literature (Ijel) 7. 5, Oct 2017, 7-16

10. Naji, Mohammad. Nature as a Victimizer in Thomas Hardy's The Mayor of Casterbridge. Reseacrchgate.net. 2012.

11. Adam, Ahmed Abdalla Saeed. "Social Protest and Elements of Reform In Elizabeth Barrett Browning Political Poems:" The Cry of The Children" and" The Runaway Slave At Pilgrim's Point." International Journal of English and Literature (Ijel) 8. 1, Feb 2018, 35-44

\section{DETAILS OF THE AUTHOR}

The author is presently working as an Assistant Professor and the Head of the Department in English, Holy Cross College, Agartala, Tripura. She has obtained her degree of Doctor of Philosophy in the field of Linguistics from JNU, New Delhi. She has to her credit published some articles and research papers in reputed journals and a few others in books. She is also the editor of a book entitled "Representing the Self: Addressing Issues of Ethnicity and Identity Across Domains" and also the co-editor of the book entitled "Contemporary Issues in Indian Literary World". Her areas of interest are primarily linguistic diversity and ethnicity in Indian sub-continent, pedagogical issues in English as a second language. 

